\title{
Figures and Tables
}

\section{Figures}

1.1 The contrasting ethical perspectives of public administration $\quad 16$

4.1 Two-D civic engagement 95

$\begin{array}{lll}4.2 & \text { Three-D civic engagement } & 97\end{array}$

5.1 State agency creation in Ireland 113

\section{Tables}

1.1 Assessment of 'The way inequalities and poverty are addressed' in Ireland

1.2 Assessment of 'How public administration is run' in Ireland 22

2.1 Contrasting functions of the state 34

3.1 A holistic understanding of social exclusion 61

5.1 Changes in public sector employment, 2008-2012 105

5.2 Changes in public sector employment using whole time equivalents

6.1 Key word analysis of departmental strategy statements, 2011-2014

6.2 Social justice in local authority corporate plans 127

6.3 Contemporary values within Irish public administration 135

6.4 Factors motivating changes in values at national and local level 136

8.1 Contrasting possibilities of public administration and social justice 